ORIGINAL ARTICLE

\title{
A method for radiologically evaluating indoor use of dimension stone considering radon exhalation rates
}

\author{
Thammiris Mohamad El Hajj'*, Mauro Pietro Angelo Gandolla², \\ Paulo Sergio Cardoso da Silva³, Eduardo Lopes Julião4, José-Luiz Gutiérrez Villanueva5 \\ and Homero Delboni Junior ${ }^{6}$ \\ IInstituto de Ciência e Tecnologia, Universidade Federal de Alfenas (Unifal-MG), Rodovia José Aurélilio Vilela, \\ Poços de Caldas-MG, Brazil; ' $E$ CONS S/A, Bioggio, Switzerland; ${ }^{3}$ Centro do Reator de Pesquisas (CRPq), \\ Instituto de Pesquisas Energéticas e Nucleares (IPEN), São Paulo, Brazil; ${ }^{4}$ nstituto de Geociências (IGC), \\ Universidade de São Paulo (USP), R. do Lago, São Paulo, Brazil; ${ }^{5}$ Radonova Laboratories, Uppsala, Sweden; \\ ${ }^{6}$ Departamento de Engenharia de Minas e de Petróleo (PMI), Universidade de São Paulo (USP), São Paulo, Brazil
}

\section{Abstract}

Background: The use of natural radioactive building materials could be a health risk for both dwellers and mining workers. Therefore, a quick and effective method to test batches of rock samples is needed. Nevertheless, there is no reference value for maximum exhalation rates for building materials, except radiological hazard indices that do not measure gas exhalation rates directly.

Objectives: This article investigated the correlations between Gamma Index and radon and thoron exhalation rates, and the proportions of radon and thoron in samples. Moreover, the main objectives were to analyze the feasibility of screening problematic samples for indoor use through a portable radiation detector (CoMo 170), which consists of a quick analysis at very low cost, and to simulate indoor concentration of radon using the measured exhalation rates of dimension stone slabs.

Design: Best-selling dimension stone slabs were submitted to the following assays: gamma spectrometry, radon and thoron exhalation analysis using scintillation cell, and radioactivity measurement using a portable detector. Univariate and multivariate statistical analyses were conducted using Statistica 13 software.

Results: The average activity concentrations measured were $971 \pm 58.6 \mathrm{~Bq} / \mathrm{kg}$ of ${ }^{40} \mathrm{~K}, 184 \pm 9 \mathrm{~Bq} / \mathrm{kg}$ of ${ }^{232} \mathrm{Th}$, and $74 \pm 3 \mathrm{~Bq} / \mathrm{kg}$ of ${ }^{226} \mathrm{Ra}$. The maximum activity concentrations of ${ }^{40} \mathrm{~K},{ }^{232} \mathrm{Th}$, and ${ }^{226} \mathrm{Ra}$ series were $1,734 \pm 100 \mathrm{~Bq} / \mathrm{kg}$, $2,667 \pm 109 \mathrm{~Bq} / \mathrm{kg}$, and $596 \pm 2 \mathrm{~Bq} / \mathrm{kg}$, respectively. The average exhalation rate of ${ }^{222} \mathrm{Rn}$ was $406 \pm 20 \mathrm{~Bq} / \mathrm{h} \mathrm{m}{ }^{2}$.

Conclusions: The main recommendations arising from this study are as follows: a portable radiation detector (CoMo 170) could be used as a screening method for selected samples; Gamma Index limit value $=1$ for dimension stone slabs could be adopted when assessing radon and thoron exhalation; and the surface radon exhalation rate should be measured as a basis of recommendation for surface treatment before sales. Finally, thoron exhalations should be considered in radiological assessment, as 57\% of the samples had higher thoron exhalation rates than radon.

Keywords: radon; thoron; gamma index; dimension stone; construction materials; radiation protection

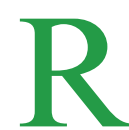

adioactive radon gas, present in the environment, is generated by the decay of uranium and thorium found in different quantities in most soils, rocks, and water. Radon and its progeny are wellknown pollutants, and there is considerable public concern about its exhalation from building materials, especially those used for indoor decoration, paving, flooring, or cladding. Thus, dimension stone (natural stone shaped and sized to meet the requirements) used in construction could be a natural source of radon, which could generate indoor concentrations higher than those recommended internationally. Brazil is a leading producer of dimension stone, which is exported mostly to the USA and Europe. While Brazil has no regulations about radon, the results should be presented carefully to avoid unnecessary public alarm, given the economic value of natural stone in international market.

Even though naturally occurring radionuclides are of primordial origin, exposure to them cannot be neglected in an impact assessment $(1,2)$. Radon, for example, occurs naturally in the environment and is one of the most studied carcinogens; several investigations relate 
carcinogenicity to dose exposure through epidemiological studies on mine workers and case studies with the general population (3-11). Moreover, there is also sufficient evidence to suggest that reducing radon exposure would benefit public health by decreasing the incidence and mortality of lung cancer $(7,12)$. A study published in the American Journal of Epidemiology, 'The Iowa Radon Lung Cancer Study' (13), states that the likelihood of developing lung cancer increases by $50 \%$ for a person exposed to daily concentrations of above $148 \mathrm{~Bq} / \mathrm{m}^{3}$.

Most of the constructions take place, or covered, with natural stones, and this must be studied to assess indoor concentrations of radon and thoron. The amount of radon exhaled from these materials depends on the following factors: radium concentration in the particles, density, grain size, pore volume, and material moisture (14). The literature distinguishes three main mechanisms of radon transport and penetration in internal environments, namely, convection via cracks and openings in the construction, diffusion, and exhalation from the ground and exhalation from building materials (15). Several international studies have dealt with the radiological assessment of building materials $(8,16-20)$, but few of them have also addressed radon and thoron measurements to evaluate radiological impact correctly. Hence, in addition to calculating the radiological hazard index proposed by the European Union (EU; Gamma Index) (21), which considers gamma emissions from ${ }^{226} \mathrm{Ra},{ }^{232} \mathrm{Th}$, and ${ }^{40} \mathrm{~K}$, this study also addresses the mass flow exhalation of radon and thoron gas from building materials, specifically dimension stone. The aim is to propose a method to radiologically evaluate the indoor use of dimension stone that includes the screening of problematic samples for indoor use through a portable radiation detector (CoMo 170), which consists of a quick analysis at very low cost; and to simulate indoor concentration of radon using the measured exhalation rates of dimension stone slabs. This method comprises a practical approach to assess whether a specific dimension stone would impose a risk considering an integrated radiological assessment.

\section{Theoretical background}

\section{Gamma index and radon regulations}

As more than one radionuclide contributes to the dose, the EU directive No. 112 (22) established a screening tool for building materials based on the maximum gamma-ray dose estimate for a given material, based on the specific activities of ${ }^{226} \mathrm{Ra}$, ${ }^{232} \mathrm{Th}$, and ${ }^{40} \mathrm{~K}$. In December 2013 , a new directive on ionizing radiation came into force in the EU, laying out uniform basic safety standards for the health protection of individuals exposed to ionizing radiation, both environmentally and occupationally $(21,23)$. This directive also reinforced the Gamma Index proposed in EU directive No. 112. Radon is addressed explicitly in Articles 54, 74, 103, and Annex XVIII. Moreover, Annex XVIII of the directive, which refers to the national radon action plan, introduces the identification of building materials with significant radon exhalation as a tool to prevent radon penetration in new buildings $(21,23,24)$. Indoor radon concentration was set at a reference level of $300 \mathrm{~Bq} / \mathrm{m}^{3}$ with a target concentration of less than $100 \mathrm{~Bq} / \mathrm{m}^{3}$, in line with the World Health Organization (WHO) recommendation $(25,26)$. The Austrian legislation is slightly different, as it already includes ${ }^{222} \mathrm{Rn}$ in the screening process (27). This study proposes a novel method, since it includes a fast screening process that can minimize radiological assessment costs. Moreover, the real surficial exhalation rate of each rock is measured and mitigation actions are proposed.

After calculating the Gamma Index, the following comparison, used as a screening tool for discerning the potential risk of specific materials, should be made: the Gamma Index should be less than 1 for a dose of $1 \mathrm{~m} \mathrm{~Sv} /$ year for bulk materials and below 6 for materials strictly used for surface applications (22). The EU regulation follows the same criterion as fixed by the International Atomic Energy Agency (IAEA) Basic Safety Standards (28) that set exemption conditions for radionuclides of natural origin. In the case of bulk material, a case-by-case basis is necessarily considered by using a dose criterion of the order of $1 \mathrm{~m} \mathrm{~Sv} / y e a r$, commensurate with typical doses due to natural background levels of radiation.

\section{The thoron issue}

The only radon isotope mentioned in international legislation is ${ }^{222} \mathrm{Rn}$, as it is believed to be responsible for most of the indoor exposure. In this type of environment, it occurs in soil as the soil is seen as the most important source of radon and, in this case, thoron would not have enough time to penetrate the building due to its short half-life (29). However, when considering construction materials as radiation sources, thoron is shown to contribute to the final concentration in the environment, and thoron progeny is inhaled mostly attached to aerosols. Nuccetelli and Bochicchio (30) affirmed that the health risk due to indoor presence of thoron is usually neglected due to its generally low indoor concentration, which is primarily caused by its short half-life. However, in specifically not uncommon situations, such as when thorium-rich building materials are used, ${ }^{220} \mathrm{Rn}$ may represent a significant source of radioactive exposure. Ishikawa et al. (31) calculated dose conversion factors for short-lived thoron decay products, analyzing a site where the dose from thoron decay products was larger than the dose from radon decay products. Lane-Smith and Wong (32), considering an area of concern close to a thoron source, concluded that the total energy released by alpha emission, inside the lungs, could be seven times greater with the effect of thoron gas instead of thoron progeny alone. 
However, since the approach to establish thoron limits is different from that of radon, this study analyzed the exhalation rates of two isotopes differently. For thoron, the effective dose equivalent by inhalation of short-lived thoron daughters as functions of the activity concentration of ${ }^{232} \mathrm{Th}$ was calculated (Equation 1) along with the total inhalation dose (Equation 2) (33):

$$
\begin{gathered}
H_{e}^{R n-220}\left(\frac{m S v}{a}\right)=4.3 \times 10^{-3} \times A^{T h-232}, \\
H_{e}\left(\frac{m S v}{a}\right)=6.3 \times 10^{-3} \times A^{R a-226}+4.3 \times 10^{-3} \times A^{T h-232},
\end{gathered}
$$

where $\mathrm{A}^{\text {Th-232 }}$ is the activity concentration of ${ }^{232} \mathrm{Th}$ and $\mathrm{A}^{\mathrm{Th}-232}$ is the activity concentration of ${ }^{226} \mathrm{Ra}$, both in $\mathrm{Bq} / \mathrm{kg}$.

\section{Experimental}

\section{Experimental setup}

In this study, we sealed three-dimension stone slabs of each rock with plastic and adhesive tape to ensure the measurement of exhalation from the plate surface only (Fig. 1). The area of each sample was measured to calculate the surficial exhalation rate (the samples were

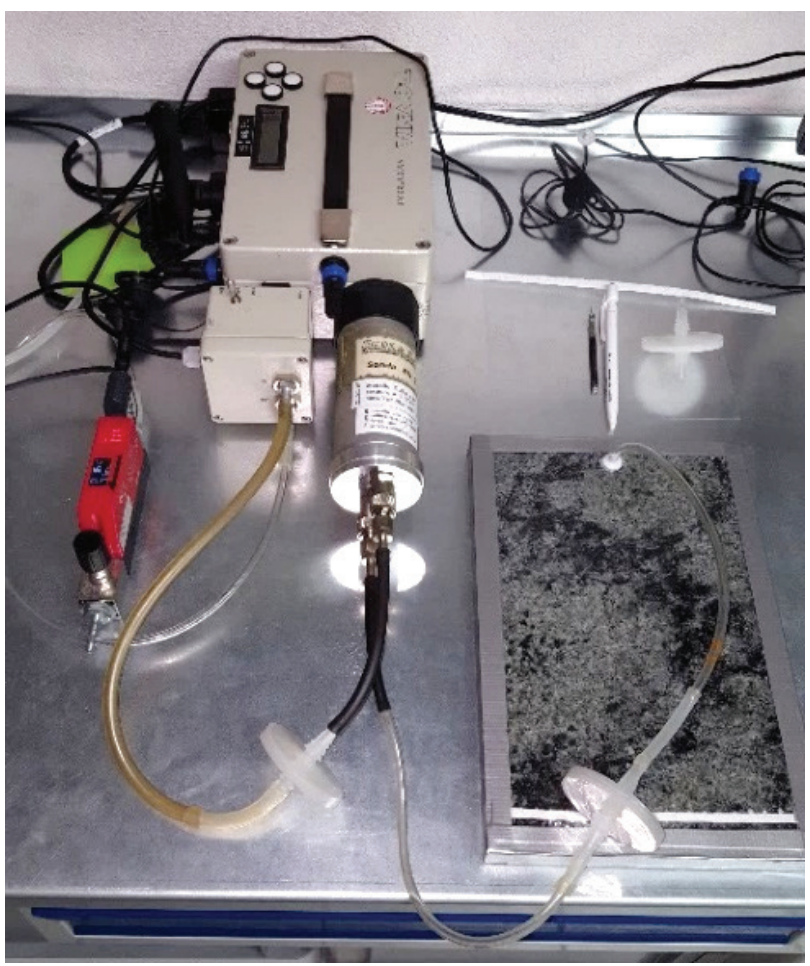

Fig. 1. Example of the experimental setup used to measure radon and thoron exhalation of the dimension stone plate sample. approximately $20 \times 20 \times 2 \mathrm{~cm}$ ). Small holes were drilled on the opposite side of air suction to ensure continuous flow and negative pressure in the system. In addition, care was taken to prevent plastic from sticking to the surface and stopping the air from flowing when the pump was connected using narrow silicone tubes glued to the inner surface of the plastic. This measure allowed us to consider that the volume between the plastic and the rock was negligible (distance between the plastic and the rock was less than $0.5 \mathrm{~mm}$ ). The radon losses due to the use of lowdensity polyvinyl chloride (PVC) plastic and adhesive tape (34) were calculated and experimentally verified, and they were negligible; the results are presented further herein. Nevertheless, there are feasible possibilities to minimize the eventual losses using specific plastics already commercially available for radon dosimetry.

Rock permeability, which is described as the path created by the connectivity of the pores where fluid flows, was measured using PDP-200 CORELAB permeameter, installed in the Basic Petrophysics Laboratory of CENPES in Rio de Janeiro, Brazil. This permeameter is specially designed to measure the permeability of tight rocks using pulse decay and nitrogen gas. Darcy Law was used to calculate matrix flow density $(\mathrm{m} / \mathrm{s})$, and the decay constant of ${ }^{222} \mathrm{Rn}$ and ${ }^{220} \mathrm{Rn}\left(\mathrm{s}^{-1}\right)$ was used to calculate diffusion lengths. As the average permeability was $(1.5 \pm 1.17) \times 10^{-18} \mathrm{~m}^{2}$, the diffusion length for ${ }^{222} \mathrm{Rn}$ was $(0.0396 \pm 0.0309) \mu \mathrm{m}$ and $(6.52 \pm 5.19) \times 10^{-6} \mu \mathrm{m}$ for ${ }^{220} \mathrm{Rn}$. These data confirm that the exhalation rate of these types of samples is only surficial, and they can be considered radon-tight samples as the thickness is more than three times the diffusion length (35). Radon concentration was measured with RadonMapper (RM) radon monitor manufactured by (TECNAVIA, Lugano, Switzerland) and approved by the Swiss Federal Institute of Metrology (METAS). The operation uses a scintillation cell (Lucas cell) presenting 5\% repeatability with built-in pressure, humidity, and temperature sensors. There are USB ports available to connect other types of sensors, for example, differential pressure. The RMs are tested periodically using a radon source, and a gap of a few hours is recommended between measurements to assure the absence of functional contamination in scintillation cell. The persistent contamination is very low, and its value could be estimated, preventing measurement biases. One of the RMs was used in passive mode to control lab concentration, which was considered the background value and subtracted from the measurements. The other two RMs were used in active mode to measure radon and thoron exhalation rates. Moreover, a flowmeter (Vögtlin Instruments, GSM-B4SA-BN00, Aesch, Switzerland) was used to keep the online track of flux during the 4-day measurement campaign for each sample; microfilters were also used to ensure that no solid particles enter the equipment, which could bias the results (Fig. 2). 


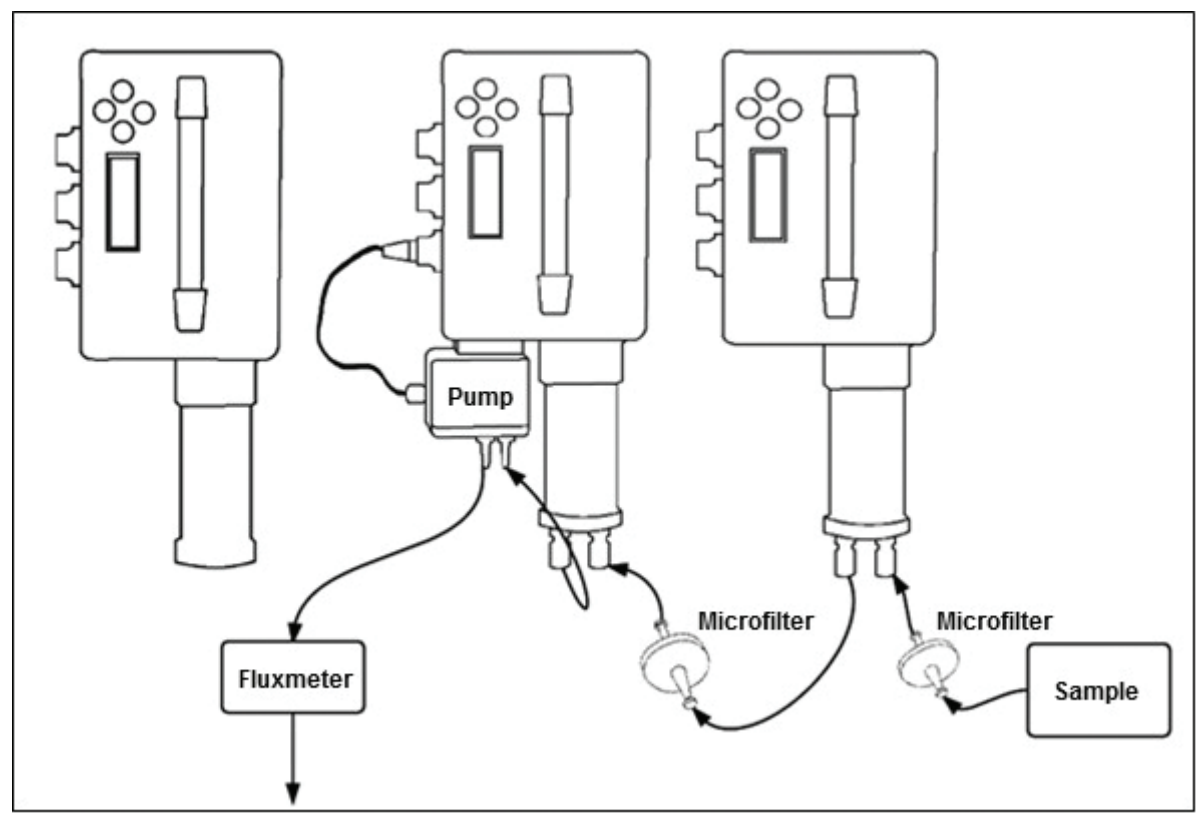

Fig. 2. Equipment setup for radon and thoron measurements using three RadonMapper monitors, two in active mode and one in passive mode (far left of the figure). The position of the flowmeter and the microfilters is also presented.

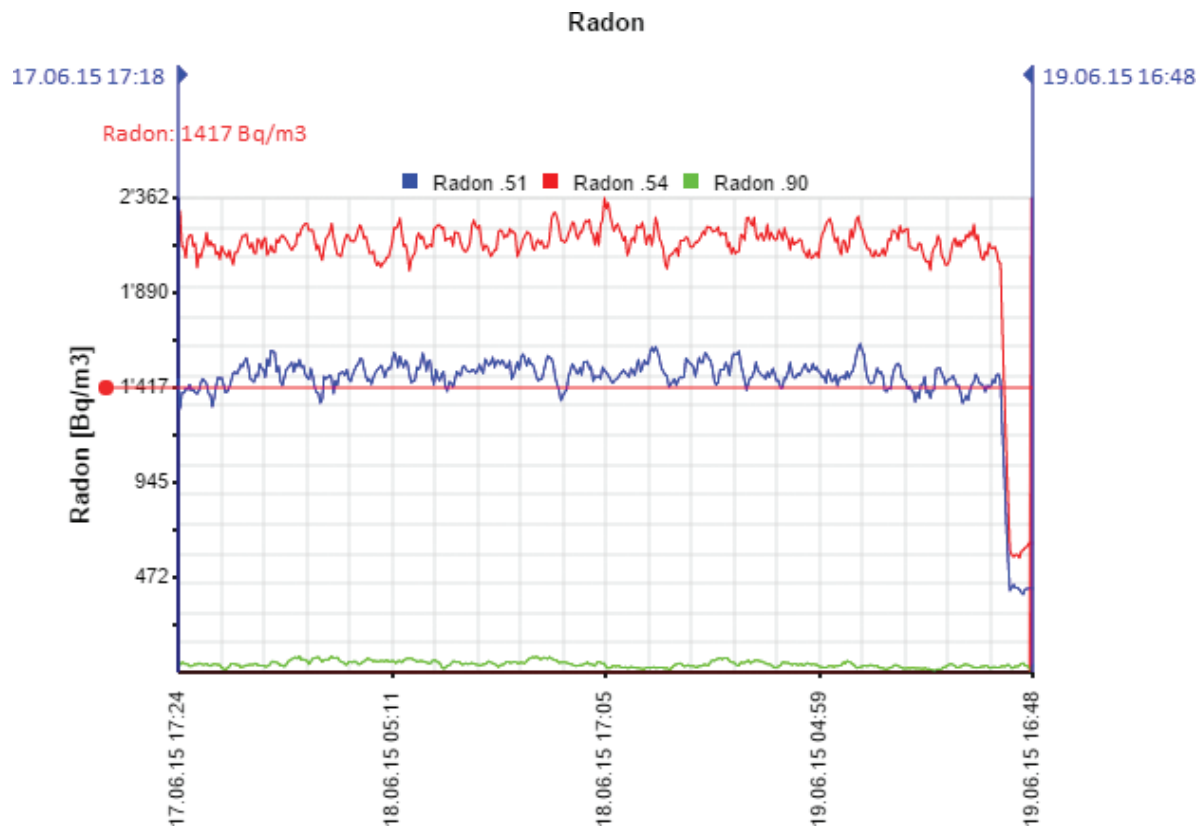

Fig. 3. Example of radon concentration graphic generated by RadonMapper software, the curve in red (Radon .54) corresponds to the first active radon monitor, the curve in blue (Radon .51) corresponds to the second active radon monitor, and the curve in green (Radon .90) is the passive radon monitor measuring the lab background concentration.

Figure 3 shows the radon concentration graphic generated by RadonMapper software. Each curve corresponds to one of the three radon monitors used. The diagram was always monitored to verify whether leakage was happening. While small oscillations in the readings are normal due to the pump, they were taken into account because we used a flowmeter integrated all the time.

\section{Measurement procedure for thoron}

After the average 4-day measurement, the scintillation cell was closed, and the pump switched off for at least 10 min to verify thoron decay for all assays. Lucas cell used in RM is calibrated for radon only and not for thoron. Thus, its indicated value requires multiplication by a correction factor (CF) to show the real value. Figure 4 


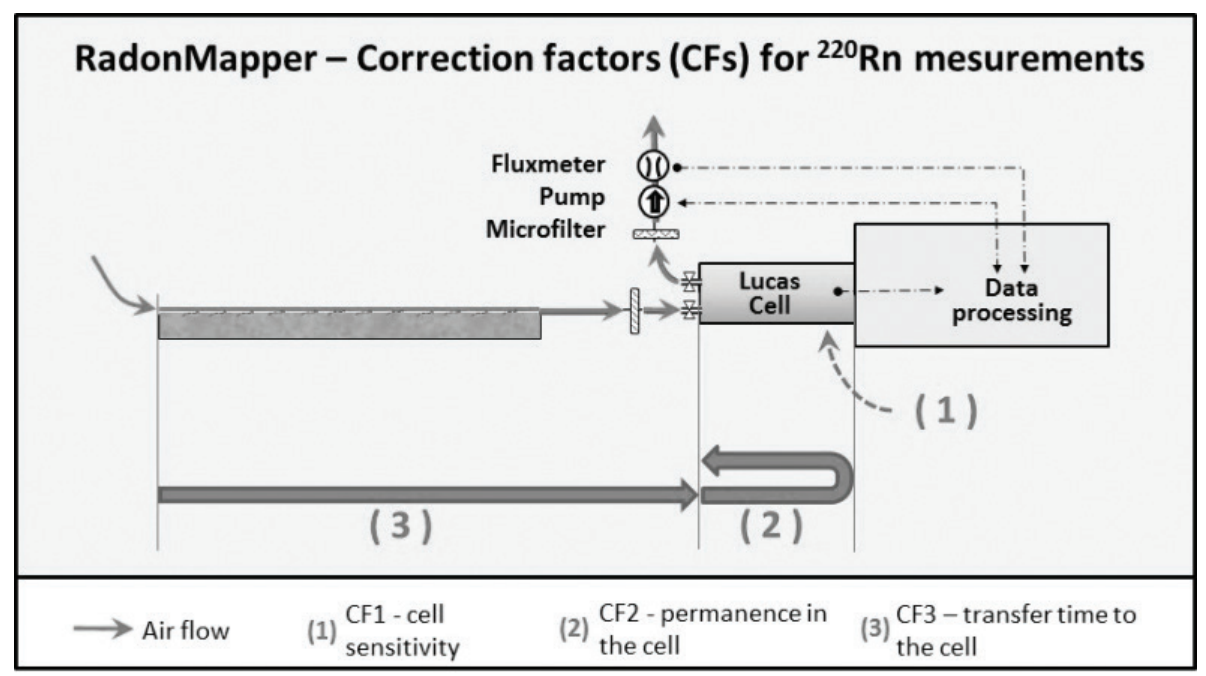

Fig. 4. Correction factors (CFs) for ${ }^{220} \mathrm{Rn}$ quantification when using the Lucas cell.

shows the three CFs used to quantify thoron exhalation, and the cell manufacturer (Mi.am, Piacenza, Italy) recommends a CF1 of 0.9 (real value/indicated value). Therefore, there is a trend toward slight overestimation to be taken into consideration. However, other CFs should also be applied, as they correct an underestimation trend due to the rapid decay of thoron in both scintillation cell and path to the cell. This underestimation depends on chamber volume and the flow adopted, since the half-life of thoron is only $55.6 \mathrm{sec}$. Several authors have recommended the use of two RMs in series, as we did in this study, with a known distance between them to calculate CF2. A known constant flux and chamber volume $(0.25 \mathrm{~L})$ allowed to calculate CF. Thus, the challenge in this strategy was to ensure a constant flow to prevent $\mathrm{CF} 2$ oscillation during the measurement. For example, for a $0.25 \mathrm{~L} / \mathrm{min}$ flow, which was adopted in most measurements in this study (average flow of $0.29 \mathrm{~L} /$ $\mathrm{min}$ ), the underestimation trend would be at least $20 \%$. CF3 depends on the sample length, the flow rate adopted, and the length of the connecting pipes used. One good strategy to calculate this underestimation is to use a tracer gas, such as $\mathrm{CO}_{2}$, at the beginning of the plate to calculate the effective time for transiting from gas to the cell. As this technique was not used in this study, only the CF1 was applied to correct the overestimation tendency; hence, the thoron measurements were limited, and the data were underestimated for this isotope.

Activity concentrations $\left(\mathrm{Bq} / \mathrm{m}^{3}\right)$ obtained using $\mathrm{RM}$ were then used to calculate the surface exhalation rates $\left(\mathrm{Bq} / \mathrm{h} \mathrm{m}^{2}\right)$ using Equation 3.

$$
C_{e}=\frac{C \times f}{A}
$$

where $C_{e}$ is the surface exhalation rate $\left(\mathrm{Bq} / \mathrm{h} \mathrm{m}^{2}\right), C$ is the radon or thoron concentration $\left(\mathrm{Bq} / \mathrm{m}^{3}\right), f$ is the flow $\left(\mathrm{m}^{3} / \mathrm{h}\right)$, and $A$ is the plate area $\left(\mathrm{m}^{2}\right)$.

\section{Indoor concentrations from surface exhalation rates}

Monitoring the buildup of radon concentration at regular time intervals in the chamber, where the sample is enclosed, is required to measure the mass exhalation rate. We used Equation 4 (36) to calculate the time needed for concentration in a room, with a volume of $56 \mathrm{~m}^{3}$ and $20 \mathrm{~m}^{2}$ of the floor covered with sampled material, to reach $100 \mathrm{~Bq} / \mathrm{m}^{3}$ and $300 \mathrm{~Bq} / \mathrm{m}^{3}$ using different air exchange rates:

$$
C(t)=\frac{J_{m} M}{V \lambda_{e}}\left[1-e^{-\lambda_{e} t}\right]+C_{0} e^{-\lambda_{e} t}
$$

where $C(t)$ is the radon concentration $\left(\mathrm{Bq} / \mathrm{m}^{3}\right)$ in the room at time $t ; J_{m}$ is the exhalation mass rate $\left(\mathrm{Bq} / \mathrm{kg} \mathrm{h}^{-1}\right) ; M$ is the total dry mass of the sample $(\mathrm{kg}) ; C_{0}\left(\mathrm{~Bq} / \mathrm{m}^{3}\right)$ is the initial amount of radon in the room $(t=0) ; V$ is the effective volume $\left(\mathrm{m}^{3}\right)$; and $\left(\mathrm{s}^{-1}\right)$ is the effective decay constant, which can be determined by the following formula: $\lambda_{e}=\lambda_{R n-222}+Q / V$, where $Q / V$ is the leak rate (LR), obtained from the ratio of airflow $(Q)$ and the volume of room $(V)$, and $\lambda_{R n-222}$ is the decay constant of ${ }^{222} \mathrm{Rn}\left(\mathrm{s}^{-1}\right)$. In these simulations, we did not consider the back diffusion of radon gas.

\section{Gamma spectrometry}

Radioisotopes activities were determined using gamma-ray spectrometric measurements. Before the application of gamma spectrometry, the sample was crushed and screened to reach a particle size of below $2 \mathrm{~mm}$. Then it was sealed in a metal can for 30 days to ensure 
equilibrium between ${ }^{226} \mathrm{Ra}$ and ${ }^{222} \mathrm{Rn}$. Specific sample activities were then determined using a Ge-hyper-pure detector (HPGe - CANBERRA Industries Inc., model GX 2020, relative efficiency of $20 \%$ and resolution of 1.9 $\mathrm{keV}$ for the ${ }^{60} \mathrm{Co}$ photopeak) located at the Poços de Caldas Laboratory (LAPOC) of the National Nuclear Energy Committee (CNEN). The reference materials RGU, RGTh, and RGK from IAEA were used for efficiency calibration, and calibrated sources of ${ }^{60} \mathrm{Co},{ }^{137} \mathrm{Cs}$, ${ }^{152} \mathrm{Eu}$, and ${ }^{241} \mathrm{Am}$, were used for energy calibration. Potassium, Th, and Ra activity concentrations were calculated using the Canberra Genie 2000 software. The equilibrium was determined by taking the mean value of three photo peaks of their progeny: ${ }^{214} \mathrm{~Pb}(295.2 \mathrm{keV}$ and 351.9 $\mathrm{keV}$ ) and ${ }^{214} \mathrm{Bi}(609.3 \mathrm{keV}) .{ }^{228} \mathrm{Ra}$ was determined by measuring the intensity of $911-\mathrm{keV}$ and $968-\mathrm{keV}$ peaks of ${ }^{228} \mathrm{Ac}$, assuming that they were in radioactive equilibrium, and the ${ }^{40} \mathrm{~K}$ was determined directly by its photo peak with 1,460-keV energy.

\section{Portable contamination monitor}

A portable contamination meter (CoMo 170 manufactured by GRAETZ) was used to analyze the counting (cps) of dimension stone samples. The aim was to verify whether this type of equipment is suitable to screen samples that could be problematic for indoor use. This equipment has an auto-calibration with an open area of $170 \mathrm{~cm}^{2}$, which provides a very sensitive means of locating radionuclides and quantifying contamination levels by alpha, beta, and gamma emitting radionuclides. This type of equipment is designed to detect high levels of radioactivity associated with contamination problems in case of accidents or equipment malfunctioning. Hence, the efficiency must not be high (and it is not), but rather the equipment response time should be fast. Therefore, this method is semi-quantitative, since it does not aim to quantify isotopes in the samples or measure the associated radioactive dose. The equipment also has a thin $\mathrm{ZnS}$ coated plastic film, which is a scintillation detector protected by a grid, and was used in this study to detect ${ }^{238} \mathrm{U}$ alpha activity (26\% efficiency) (37) and ${ }^{40} \mathrm{~K}$ beta and gamma activity (30\% efficiency) (37) present in natural rocks. This equipment was acquired to perform this study, so the film had no previous contamination. The background value was measured before each analysis and subtracted from the assay results. The net counting rate is reported in Table 1.

\section{Results and discussion}

The experimental results obtained by the contamination monitor, gamma spectrometry, and scintillation cell are presented in Table 1 for 21 of 35 samples analyzed, and the full dataset is available for consultation. Importantly, the samples that showed alpha activity detected by the contamination monitor were also the ones with the highest Gamma Index and total radon exhalation rates. Moreover, Gamma Index only helps to discern the potential risk and cannot be used to predict radon exhalation from dimension stone. While Gamma Index $=6$ is recommended for surface rocks by the EU regulation, it did not correlate at all with hazardous exhalations, leading to the adoption of Gamma Index $=1$. The average activity concentrations measured were $971 \pm 59 \mathrm{~Bq} / \mathrm{kg}$ for ${ }^{40} \mathrm{~K}, 184 \pm 9 \mathrm{~Bq} / \mathrm{kg}$ for ${ }^{232} \mathrm{Th}$, and $74 \pm 3 \mathrm{~Bq} / \mathrm{kg}$ for ${ }^{226} \mathrm{Ra}$. The maximum activity concentrations of the ${ }^{40} \mathrm{~K}$, ${ }^{232} \mathrm{Th}$, and ${ }^{226} \mathrm{Ra}$ series were $1,738 \pm 100 \mathrm{~Bq} / \mathrm{kg}, 2,667 \pm$ $109 \mathrm{~Bq} / \mathrm{kg}$, and $596 \pm 2 \mathrm{~Bq} / \mathrm{kg}$, respectively. When comparing the results with other granite analyses, for example, in the USA, these values show that the Brazilian dimension stone are enriched in thorium in their formation (38). From the analysis of 39 granite countertops, Myatt et al. (38) reported the value of $231 \mathrm{~Bq} / \mathrm{kg}$ for the maximum activity concentration of ${ }^{232} \mathrm{Th}$ and an average value of $72 \mathrm{~Bq} / \mathrm{kg}$. Therefore, the radiological assessment of the rocks addressed in this research must be different because the thoron participation in the individual dose rate is much higher than the one reported commonly in the literature. The average exhalation rate of ${ }^{222} \mathrm{Rn}$ was $406 \pm 20 \mathrm{~Bq} / \mathrm{h} \mathrm{m}^{2}$, which is much higher than the result reported by Allen et al. (39) for 39 granite countertops in the USA. This difference could be interpreted by the influence of geological genesis factors in the sample radioactivity and it highlights the importance of assessing each lot of dimension stone sold for indoor use.

${ }^{222} \mathrm{Rn}$ exhalation rates were calculated using Equation 4, and these would reach the limits of $300 \mathrm{~Bq} / \mathrm{m}^{3}$ and $100 \mathrm{~Bq} / \mathrm{m}^{3}$ in $1 \mathrm{~h}$ for different scenarios in a room of $56 \mathrm{~m}^{3}$ with $20 \mathrm{~m}^{2}$ of rock used as floor coverage. This approach was only used for ${ }^{222} \mathrm{Rn}$, as the concentration due to thoron builds up very slowly, resulting from the much shorter ${ }^{220} \mathrm{Rn}$ half-life, which would be disturbed by any leakage rate in the room. Table 2 presents the results obtained for this simulated room. This calculation is only an example but could help in the radiological assessment of radon concentration in a room when someone is interested in buying a new floor or a countertop for house. It is also helpful when verifying whether a room needs to increase air exchange or whether the area covered with a particular rock should be restricted. Therefore, the $J_{m}$ exhalation limit could be updated, depending on the real scenario of a room in a dwelling, and it hinges on the ventilation rate and the time spent in this room.

When comparing the values of Gamma Index with total radon exhalations, 12 samples, one sample with Gamma Index $=1$ and 11 samples with Gamma Index $>1$ showed ${ }^{222} \mathrm{Rn}$ exhalation rate higher than $140 \mathrm{~Bq} / \mathrm{h} \mathrm{m}^{2}$, which is the strictest scenario. On the other hand, only 


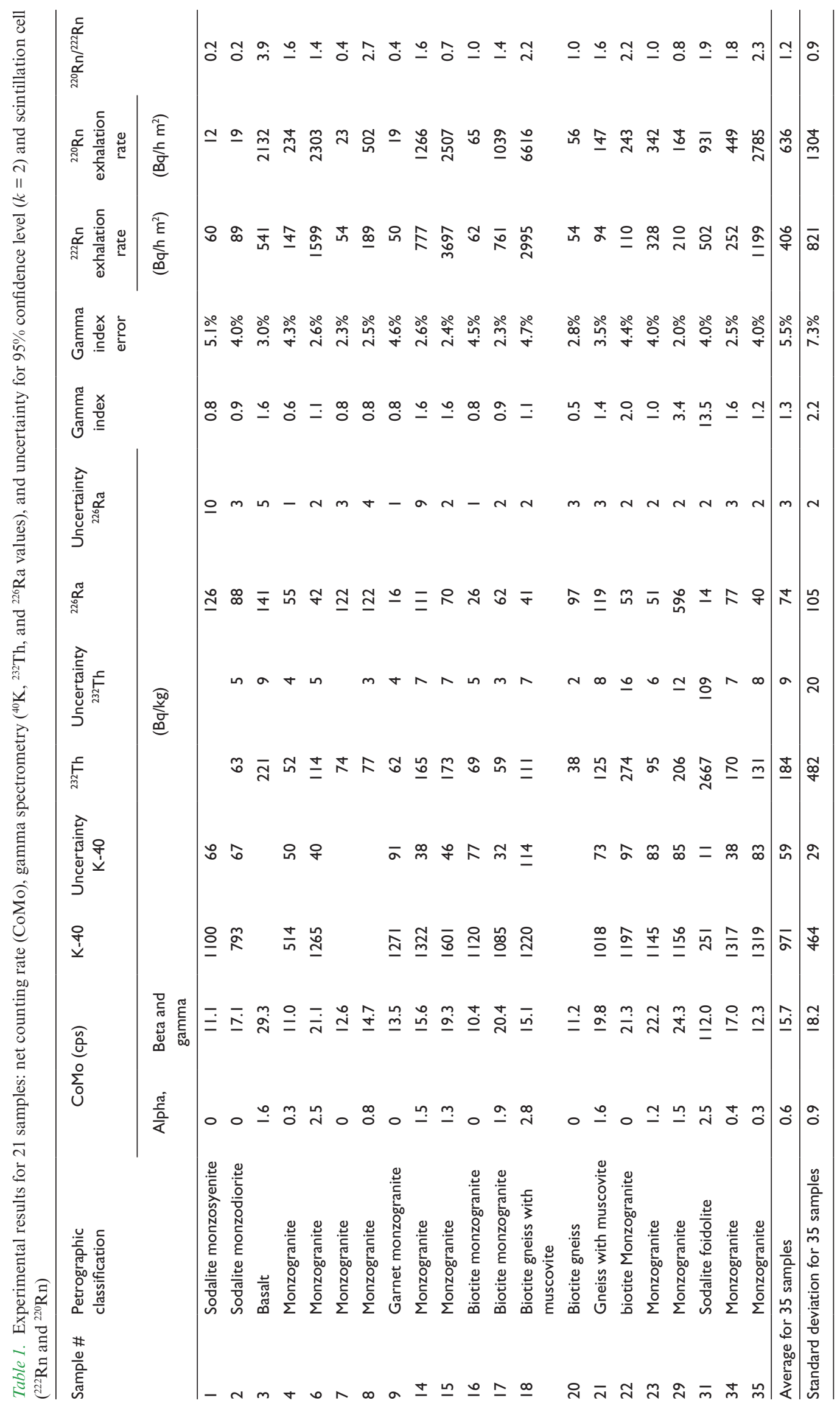


four samples with Gamma Index $=1$ showed exhalation rates higher than $840 \mathrm{~Bq} / \mathrm{h} \mathrm{m}^{2}$, which is a less strict value. Additionally, three samples showed Gamma Index $<1$ and exhaled ${ }^{222} \mathrm{Rn}$ values higher than $140 \mathrm{~Bq} / \mathrm{h} \mathrm{m}^{2}$ : Sample $4\left(\right.$ Gamma Index $=0.6$ and $\left.147 \pm 7 \mathrm{~Bq} / \mathrm{h} \mathrm{m}^{2}\right)$, Sample 8 $\left(\right.$ Gamma Index $=0.8$ and $\left.189 \pm 9 \mathrm{~Bq} / \mathrm{h} \mathrm{m}^{2}\right)$, and Sample $17\left(\right.$ Gamma Index $=0.9$ and $\left.761 \pm 31 \mathrm{~Bq} / \mathrm{h} \mathrm{m}^{2}\right)$. In conclusion, all samples with Gamma Index $>1$ showed ${ }^{222} \mathrm{Rn}$ exhalation values higher than $140 \mathrm{~Bq} / \mathrm{h} \mathrm{m}^{2}$ but not all samples with exhalations higher than the stricter value exceeded Gamma Index $>1$.

Table 2. Exhalation rates $\left(J_{m}\right)$ calculated based on the time $(1 \mathrm{~h})$ to reach concentration limits for an indoor room

\begin{tabular}{lcc}
\hline Condition & $\begin{array}{c}J_{m} \text { to reach } \\
300 \mathrm{~Bq} / \mathrm{h} \text { in I h }\end{array}$ & $\begin{array}{c}J_{m} \text { to reach } \\
100 \mathrm{~Bq} / \mathrm{h} \text { in I h }\end{array}$ \\
\hline $\begin{array}{l}\text { Air exchange of } 0.36 \mathrm{~h}^{-1} \\
\text { and background }=0\end{array}$ & $840 \mathrm{~Bq} / \mathrm{h} \mathrm{m}^{2}$ & $700 \mathrm{~Bq} / \mathrm{h} \mathrm{m}^{2}$ \\
$\begin{array}{l}\text { Air exchange of } 0.36 \mathrm{~h}^{-1} \\
\text { and background }=50 \mathrm{~Bq} / \mathrm{m}^{3}\end{array}$ & $280 \mathrm{~Bq} / \mathrm{h} \mathrm{m}^{2}$ & $140 \mathrm{~Bq} / \mathrm{h} \mathrm{m}^{2}$ \\
\hline
\end{tabular}

\section{Simulation of indoor radon concentrations}

As a way of verifying compliance with the legislation in force in the EU and the WHO recommendations, exhalation values, presented in Table 3, were calculated based on the ${ }^{222} \mathrm{Rn}$ surface exhalation rate. Table 3 shows the results obtained from Equation 4 for 21 of the 35 samples analyzed, and the full dataset is available for consultation. We conclude that $11 \%$ of the samples would reach the EU-recommended concentration in less than $1 \mathrm{~h}, 23 \%$ in less than $2 \mathrm{~h}$, and $80 \%$ of the samples reach the limit in less than $24 \mathrm{~h}$. Considering the target concentration recommended by the WHO, 100\% of the samples would reach this limit in $24 \mathrm{~h}$. These results were obtained considering $C_{0}$ (background concentration) and LR (leakage rate or air renewal rate) equal to zero, which is an unrealistic scenario. Table 3 presents simulations with a realistic air renewal rate.

Time to reach the limits of $100 \mathrm{~Bq} / \mathrm{m}^{3}$ and $300 \mathrm{~Bq} / \mathrm{m}^{3}$ is considerably higher when fresh air is added into the environment (air renewal rate [LR] in $\mathrm{s}^{-1}$ ). However, samples with high exhalation rates could be dangerous for human health, even in case of air exchange, especially in places

Table 3. Simulation of time to reach indoor radon concentrations under different conditions, sorting 21 samples by decreasing exhalation rates of ${ }^{222} \mathrm{Rn}$

\begin{tabular}{|c|c|c|c|c|c|c|c|c|}
\hline \multirow[t]{3}{*}{ Sample } & \multirow[t]{3}{*}{$\begin{array}{l}\text { Petrographic } \\
\text { classification }\end{array}$} & \multirow{3}{*}{$\begin{array}{l}\text { Surface exhalation } \\
\text { rate }\left(\mathrm{Bq} / \mathrm{h} \mathrm{m}^{2}\right)\end{array}$} & \multicolumn{2}{|c|}{$\begin{array}{l}20 \mathrm{~m}^{2} \text { of rock in a } 56 \mathrm{~m}^{3} \\
\text { room with } L R=0\end{array}$} & \multicolumn{2}{|c|}{$\begin{array}{l}20 \mathrm{~m}^{2} \text { of rock in a } 56 \mathrm{~m}^{3} \\
\text { room with } L R=0.36 \mathrm{~h}^{-1}\end{array}$} & \multicolumn{2}{|c|}{$\begin{array}{c}20 \mathrm{~m}^{2} \text { of rock in a } 56 \mathrm{~m}^{3} \text { room } \\
\text { with } \mathrm{LR}=0.36 \mathrm{~h}^{-1} \text { and } \\
\text { background }=50 \mathrm{~Bq} / \mathrm{m}^{3}\end{array}$} \\
\hline & & & $100 \mathrm{~Bq} / \mathrm{m}^{3}$ & $300 \mathrm{~Bq} / \mathrm{m}^{3}$ & $100 \mathrm{~Bq} / \mathrm{m}^{3}$ & $300 \mathrm{~Bq} / \mathrm{m}^{3}$ & $100 \mathrm{~Bq} / \mathrm{m}^{3}$ & $300 \mathrm{~Bq} / \mathrm{m}^{3}$ \\
\hline & & & Time $(\min )$ & Time $(\min )$ & Time $(\min )$ & Time $(\min )$ & Time (min) & Time (min) \\
\hline 15 & Monzogranite & 3,697 & 4.5 & 13.6 & 219.4 & 658.3 & 2.3 & 11.4 \\
\hline 18 & $\begin{array}{l}\text { Biotite gneiss with } \\
\text { muscovite }\end{array}$ & 2,995 & 5.6 & 16.8 & 270.9 & 812.6 & 2.8 & 14.0 \\
\hline 6 & Monzogranite & I,599 & 10.5 & 31.5 & 507.3 & I522.I & 5.3 & 26.3 \\
\hline 35 & Monzogranite & 1,199 & 14.0 & 42.0 & 676.6 & 2029.9 & 7.0 & 35.0 \\
\hline 14 & Monzogranite & 777 & 21.6 & 64.9 & 1044.I & 3132.4 & 10.8 & 54.1 \\
\hline 17 & Biotite monzogranite & 761 & 22.1 & 66.2 & 1066.0 & 3198.2 & 11.0 & 55.2 \\
\hline 3 & Basalt & 541 & 31.1 & 93.2 & 1499.6 & 4498.9 & 15.5 & 77.6 \\
\hline 31 & Sodalite foidolite & 502 & 33.5 & 100.4 & 1616.1 & 4848.4 & 16.7 & 83.7 \\
\hline 23 & Monzogranite & 328 & 51.2 & 153.7 & 2473.4 & 7420.8 & 25.6 & 128.1 \\
\hline 34 & Monzogranite & 252 & 66.7 & 200.0 & 3219.4 & 9659.2 & 33.3 & 166.7 \\
\hline 29 & Monzogranite & 210 & 80.0 & 240.0 & 3863.3 & $1159 \mid .4$ & 40.0 & 200.0 \\
\hline 8 & Monzogranite & 189 & 88.9 & 266.7 & 4292.6 & 12879.7 & 44.4 & 222.3 \\
\hline 4 & Monzogranite & 147 & 114.3 & 342.9 & 5519.1 & 16560.6 & 57.2 & 285.8 \\
\hline 22 & Biotite monzogranite & 110 & 152.7 & 458.2 & 7375.8 & 22133.2 & 76.4 & 382.0 \\
\hline 21 & Gneiss with muscovite & 94 & 178.7 & 536.2 & 8631.5 & 25902.3 & 89.4 & 447.0 \\
\hline 2 & Sodalite monzodiorite & 89 & 188.8 & 566.3 & 9116.5 & 27358.1 & 94.4 & 472.2 \\
\hline 16 & Biotite monzogranite & 62 & 271.0 & 812.9 & | 3087.5 & 39280.3 & 135.5 & 678.0 \\
\hline 1 & Sodalite monzosyenite & 60 & 280.0 & 840.0 & 13523.8 & 40590.6 & 140.0 & 700.6 \\
\hline 7 & Monzogranite & 54 & 311.1 & 933.3 & 15026.8 & 45104.2 & 155.6 & 778.5 \\
\hline 20 & Biotite Gneiss & 54 & 311.1 & 933.3 & 15026.8 & 45104.2 & 155.6 & 778.5 \\
\hline 9 & Garnet monzogranite & 50 & 336.0 & 1008.0 & 16229.3 & $487 I 5.7$ & 168.1 & 840.8 \\
\hline
\end{tabular}


with low air renewal rates, such as cold weather countries. Therefore, alternative uses of these rocks should be investigated, either by limiting the area covered by this rock or using complementary surface treatment. The average indoor concentration found in researches worldwide varies between $21 \mathrm{~Bq} / \mathrm{m}^{3}$ and $80 \mathrm{~Bq} / \mathrm{m}^{3}(12,25)$, mainly from soil and almost exclusively from ${ }^{222} \mathrm{Rn}$. By adding this initial concentration value $C_{0}$, the time to reach the stipulated limits drops significantly (98.3\%), as observed in the last two columns of Table 3. This fact reinforces the need for calculating the exhalation rate value acceptable to be used for sample screening. If a problematic sample is found, surface treatment could be applied. For example, $20 \mathrm{~m}^{2}$ of a dimension stone in a $56 \mathrm{~m}^{3}$ room with an exhalation rate of $140 \mathrm{~Bq} / \mathrm{h} \mathrm{m}^{2}$ would build up the ${ }^{222} \mathrm{Rn}$ concentration to $100 \mathrm{~Bq} / \mathrm{m}^{3}$ and $300 \mathrm{~Bq} / \mathrm{m}^{3}$ in less than 1 and $4 \mathrm{~h}$, respectively, with an LR of $2 \mathrm{~m}^{3} / \mathrm{h} /$ person $\left(0.37 \mathrm{~h}^{-1}\right)$ and background equal to $50 \mathrm{~Bq} / \mathrm{m}^{3}$.

Using an exhalation rate of $140 \mathrm{~Bq} / \mathrm{h} \mathrm{m}^{2}$ for ${ }^{222} \mathrm{Rn}$ as a criterion, $39 \%$ of the samples tested in this study would need to be submitted to an additional polishing or waterproofing treatment. If surface treatment is not used, care should be taken in the indoor use of these rocks. The limiting criteria to be followed in these cases could be to restrict the covered area, limit the use of this material to a few square meters in well-ventilated sites or in places where people do not remain for an extended time such as corridors and laundries.

\section{Leakage and reproducibility tests for radon measurements}

Figure 5a shows the setup used to assess radon losses through plastic membrane and adhesive tape. RadonMapper 1 receives the flow from radon source, it then passes through the first plastic membrane and goes into RM 2 before going outdoor. As a double check mechanism, we used a second plastic membrane of $0.5 \mathrm{~mm}$ above the first one to check eventual losses using two RMs in a closed circuit. A fifth RM was also used in passive mode to check the background of the room, but it is not presented in Fig. 5a. Figure 5b shows average concentrations for the $36 \mathrm{~h}$ of measurement, which were as follows: $382 \pm 23 \mathrm{~Bq} / \mathrm{m}^{3}$ for RM1, $377 \pm 25 \mathrm{~Bq} / \mathrm{m}^{3}$ for $\mathrm{RM} 2,40 \pm 8 \mathrm{~Bq} / \mathrm{m}^{3}$ for $\mathrm{RM} 3$, and $41 \pm 8 \mathrm{~Bq} / \mathrm{m}^{3}$ for RM4 . The background of the lab was $41 \pm 9 \mathrm{~Bq} / \mathrm{m}^{3}$. Therefore, since radon losses are within the detection limit of equipment, it could be considered negligible.

Six samples were measured in two labs by independent teams to check the reproducibility of radon measurements, and the results are presented in Table 4 . The average standard deviation between labs was $9 \%$, which shows a good level of reproducibility of this method $(40,41)$. However, we did not perform direct repeatability testing of the method, which should be done in further studies.

\section{Effective dose equivalent for short-lived thoron progeny}

Table 5 shows the overall inhalation dose equivalent and the effective dose equivalent for short-lived ${ }^{220} \mathrm{Rn}$ daughter's results. They allow us to conclude that ${ }^{220} \mathrm{Rn}$ cannot be neglected for the samples studied in this research since $61.7 \%$ of the total average dose is due to ${ }^{220} \mathrm{Rn}$ contribution. This assessment is limited because we include only the thoron progeny dose, not the thoron gas itself. The dose was calculated using Equations 1 and 2 as proposed by Keller et al. (33) since not all the biases of thoron exhalation rates were solved in the campaign. However, the results were consistent with the exhalation rates measured. The purpose of thoron measurements was to show how important it could be when assessing some types of thorium-enriched samples. For all further analyses in this study, only ${ }^{222} \mathrm{Rn}$ exhalation rates were considered.

\section{Statistical analysis regarding the screening method}

Table 6 presents Spearman correlation coefficients calculated for alpha, beta, and gamma counting (cps), Gamma Index, and ${ }^{222} \mathrm{Rn}$ - and ${ }^{220} \mathrm{Rn}$-exhalation rates. The results show significant correlation, with $95 \%$ confidence level $(P<0.01)$ between the following variables: alpha count and beta and gamma count (0.703); alpha count with Gamma Index (0.667); alpha count and ${ }^{222} \mathrm{Rn}(0.802)$; alpha count and ${ }^{220} \mathrm{Rn}(0.784)$; beta and gamma count

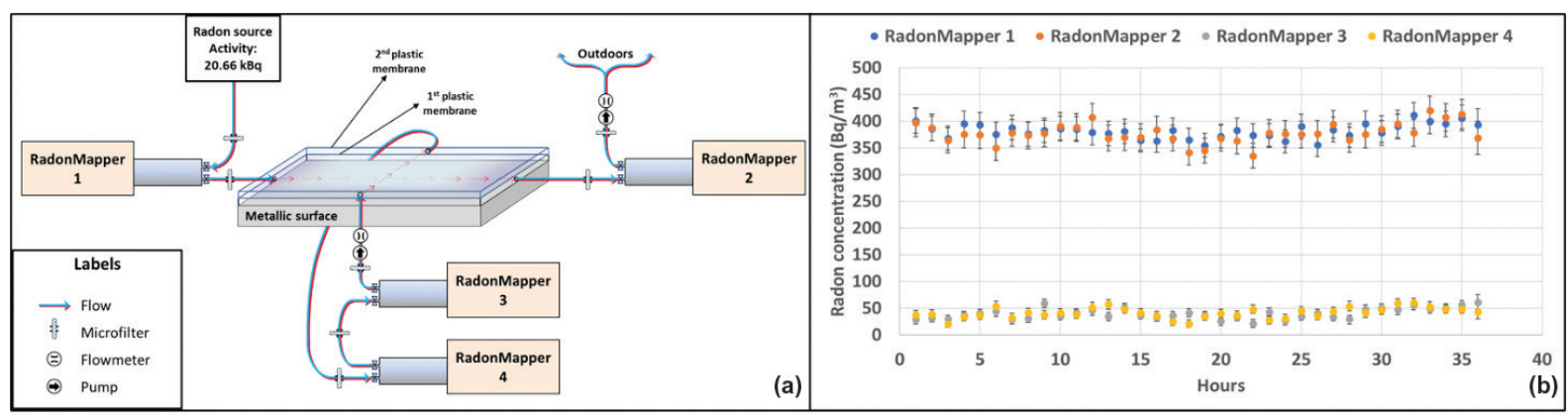

Fig. 5. (a) Scheme used to test radon losses through plastic membrane and adhesive tape; (b) radon concentrations measured by RMs using the configuration shown in (a). 
Table 4. Surface exhalation rates $\left(\mathrm{Bq} / \mathrm{h} \mathrm{m}^{2}\right)$ and uncertainties measured in Labs A and $\mathrm{B}$ for six samples

\begin{tabular}{lccccc}
\hline Sample \# & $\begin{array}{c}\text { Surface exhalation rate } \\
\left(\mathrm{Bq} / \mathrm{h} \mathrm{m}^{2}\right)-\text { Lab A }\end{array}$ & Uncertainty - Lab A & $\begin{array}{c}\text { Surface exhalation rate } \\
\left(\mathrm{Bq} / \mathrm{h} \mathrm{m}^{2}\right)-\text { Lab B }\end{array}$ & $\begin{array}{c}\text { Uncertainty - Lab B } \\
\text { Relative standard } \\
\text { deviation (\%) }\end{array}$ \\
\hline 3 & 1954 & 129 & 2132 & 134 & 6 \\
20 & 68 & 17 & 56 & 15 & 14 \\
21 & 178 & 26 & 147 & 20 & 13 \\
27 & 115 & 23 & 123 & 26 & 5 \\
28 & 44 & 15 & 36 & 73 & 14 \\
31 & 893 & 66 & 931 & & 3 \\
\hline Average & & & & 9 \\
\hline
\end{tabular}

Table 5. Effective dose equivalent for ${ }^{220} \mathrm{Rn}$ short-lived daughters $\left(\mathrm{He}-{ }^{220} \mathrm{Rn}\right)$ and the overall inhalation dose equivalent $(\mathrm{He})$

\begin{tabular}{lcc}
\hline Results for 33 samples & $\mathrm{He}(\mathrm{mSv} / \mathrm{y})$ & $\mathrm{He}-{ }^{220} \mathrm{Rn}(\mathrm{mSv} / \mathrm{y})$ \\
\hline Average & 1.07 & 0.66 \\
Standard deviation & 2.0 & 1.9 \\
Maximum & 11.56 & 11.47 \\
\hline
\end{tabular}

Table 6. Spearman correlation ranking for alpha activity, beta and gamma activities, Gamma Index, and $J_{m}{ }^{222} \mathrm{Rn}$ and $J_{m}{ }^{220} \mathrm{Rn}$ (exhalation rates of ${ }^{222} \mathrm{Rn}$ and ${ }^{220} \mathrm{Rn}$ )

\begin{tabular}{|c|c|c|c|c|c|}
\hline \multicolumn{6}{|c|}{ Spearman correlation ranking - highlighted correlations are significant for $P<0.01000$} \\
\hline Variables & Alpha (cps) & Beta and gamma (cps) & Gamma index & $\int_{m}{ }^{222} \mathrm{Rn}$ & $J_{m}{ }^{220} \mathrm{Rn}$ \\
\hline Alpha (cps) & 1.000 & & & & \\
\hline Beta and gamma (cps) & 0.703 & 1.000 & & & \\
\hline Gamma Index & 0.667 & 0.911 & 1.000 & & \\
\hline$J_{m}{ }^{222} \mathrm{Rn}$ & 0.802 & 0.715 & 0.772 & 1.000 & \\
\hline$J_{m}{ }^{220} \mathrm{Rn}$ & 0.784 & 0.678 & 0.736 & 0.879 & 1.000 \\
\hline
\end{tabular}

and Gamma Index (0.911); beta and gamma count and ${ }^{222} \mathrm{Rn}(0.715)$; beta and gamma count and ${ }^{220} \mathrm{Rn}(0.678)$; Gamma Index and ${ }^{222} \mathrm{Rn}$ (0.772); Gamma Index and ${ }^{220} \mathrm{Rn}$ (0.736); and ${ }^{222} \mathrm{Rn}$ and ${ }^{220} \mathrm{Rn}(0.879)$.

Figure 6 presents the linear regression equation for Gamma Index and beta and gamma variables. For 95\% confidence level, the value of $r$ (Pearson correlation coefficient for samples) represents, in the exact hypothesis test, the rejection of null hypothesis, that is, $\mathrm{H}_{0}:|\rho|=0$. Hence, there is statistical evidence of a linear correlation between Gamma Index and beta and gamma variables. The confidence interval for $\rho$ (Pearson's population correlation coefficient) using Fisher's $Z$-approximation is $0.940 \leq \rho \leq 0.985$. For the one-tailed test, $0.946 \leq \rho$ indicates a robust positive correlation (above 0.9 ), and the population $R^{2}$ (coefficient of determination) $\geq 0.894$, which shows that the variables explain its variation in $89.4 \%$ for a sample of 35 elements.

Figure 7 shows the distribution of residuals for beta and gamma count and the Gamma Index. It is possible to conclude that the data follow a normal distribution with a strong correlation between them, which corroborates the analysis shown in Fig. 6.
Figure 8 shows the representation of confidence interval in dashed lines for the same linear regression presented in Fig. 6 to predict the dependent variable. For Gamma Index $\geq 1$, all samples present values for beta and gamma

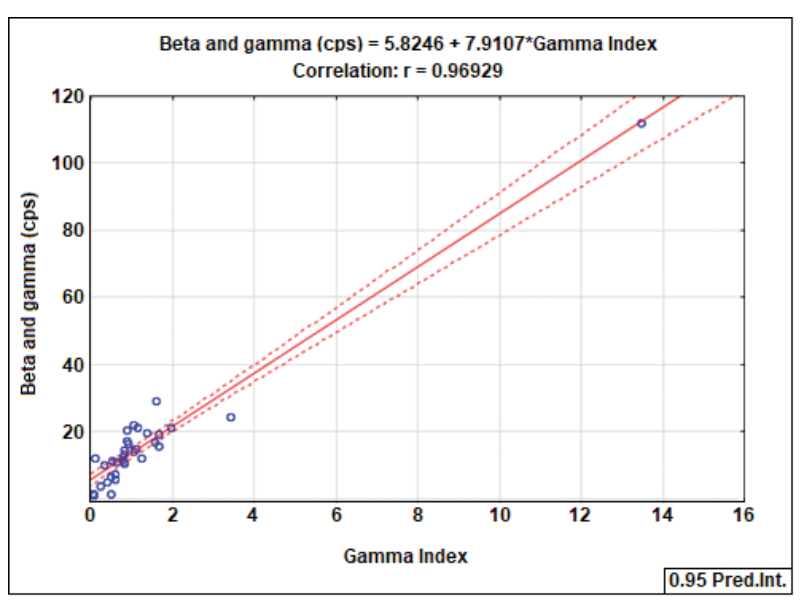

Fig. 6. Linear regression - beta and gamma count and gamma index. 

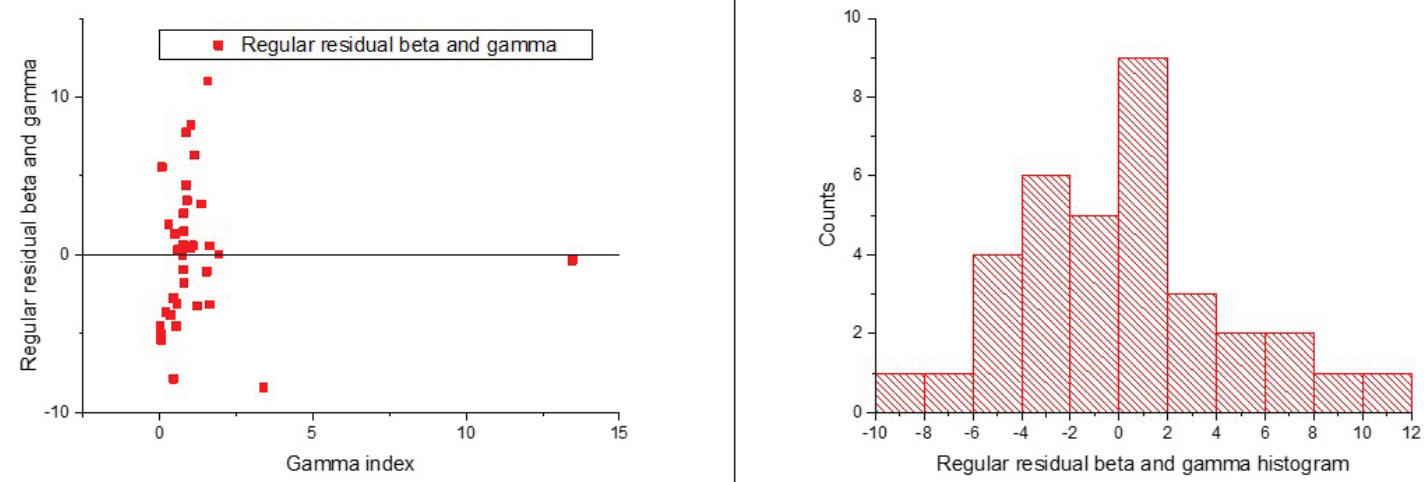

Fig. 7. Residual distribution of beta and gamma count and the gamma index.

greater than or equal to $13.7 \mathrm{cps}$. Therefore, the Gamma Index can indirectly be inferred by measurements with portable radiation detector.

Consequently, it is possible to conclude that non-zero alpha count and/or beta and gamma counts equal to or higher than $10 \mathrm{cps}$ are the recommended values used for this primary screening. The value of $10 \mathrm{cps}$ is considered conservative in this case. A security factor of 1.37 , which is a coefficient employed to prevent uncertainties, was applied to have a stricter screening value to avoid false negatives. However, by decreasing the security factor, values higher than 10 are obtained but are less security-friendly. By this method, $26 \%$ of the samples of this study would be approved for indoor use without a need for additional exhalation assessments and radiological hazard indices. More data could decrease this value.

\section{Surface treatment}

Techniques to reduce and control the effects of radon pollution indoors have been studied, and even an anti-radon coating was developed and patented (42). However, for dimension stone slabs, a much simpler and cheaper technique, namely polishing, could be used to decrease radon exhalation rates. Thus, this study investigated this technique by analyzing rough and polished surfaces of each sample. Table 7 shows that there is an average decrease of $25 \%$ in total $\mathrm{Rn}$ exhalation for the studied samples when the surface of the dimension stone is polished. While the reduction is present in almost all samples studied due to less exhalation of ${ }^{222} \mathrm{Rn}$, it was not consistent for ${ }^{220} \mathrm{Rn}$. However, when narrowing down the samples to those that exhale more than $140 \mathrm{~Bq} / \mathrm{h} \mathrm{m}^{2}$, the thoron reduction is consistent. This technique could be used as a surface treatment to enable safe indoor use of dimension stone slabs. After polishing, if the samples still present high exhalation rates, an oil/water-phobic substance could be applied to decrease the exhalation rate. The commercial

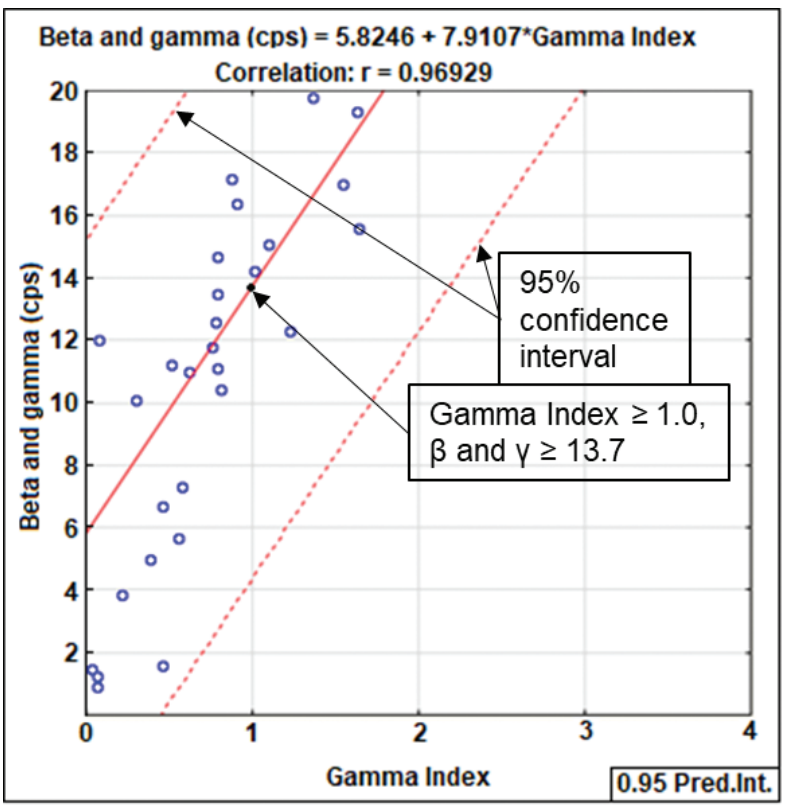

Fig. 8. Regression graph of Gamma Index and beta and gamma count (cps) variables, showing the confidence interval.

substance tested in this study is called PEK Bio, which is designed to avoid stains in dimension stone, preserving the natural beauty of the rock. Using this substance caused an additional 30\% decrease in exhalation rate (relative decrease of $29 \%$ for ${ }^{222} \mathrm{Rn}$ and $31 \%$ for ${ }^{220} \mathrm{Rn}$ ). While the long-term efficiency of the surface treatment was not monitored, the promising results recommend this analysis for the future studies.

\section{Proposed method}

Figure 9 presents the method proposed for indoor use of a batch of dimension stone. In principle, the approval of a particular material cannot occur only once per mine because even for an apparently homogeneous 
Table 7. Radon exhalations before and after polishing the dimension stone slabs

\begin{tabular}{|c|c|c|c|c|c|}
\hline \multirow[t]{2}{*}{ Sample \# } & \multirow[t]{2}{*}{ Petrographic classification } & \multirow{2}{*}{$\begin{array}{c}\text { Polished } \\
\begin{array}{c}\text { Rn-exhalation } \\
\left(\mathrm{Bq} / \mathrm{h} \mathrm{m}^{2}\right)\end{array}\end{array}$} & \multirow{2}{*}{$\begin{array}{c}\text { Not polished } \\
\begin{array}{c}\text { Rn-exhalation } \\
\left(\mathrm{Bq} / \mathrm{h} \mathrm{m}^{2}\right)\end{array}\end{array}$} & \multicolumn{2}{|c|}{ Rn-total } \\
\hline & & & & $\begin{array}{l}\text { Absolute } \\
\text { difference }\end{array}$ & $\begin{array}{l}\text { Relative } \\
\text { difference }\end{array}$ \\
\hline $\mathrm{I}$ & Sodalite monzosyenite & 72 & 66 & 6 & $9.09 \%$ \\
\hline 2 & Sodalite monzodiorite & 108 & 114 & -6 & $-5.26 \%$ \\
\hline 3 & Basalt & 2,673 & 3,306 & -633 & $-19.15 \%$ \\
\hline 7 & Monzogranite & 77 & 80 & -3 & $-3.75 \%$ \\
\hline 8 & Monzogranite & 691 & 1,238 & -547 & $-44.18 \%$ \\
\hline 9 & Garnet monzogranite & 69 & 147 & -78 & $-53.06 \%$ \\
\hline 10 & Syenogranite & 74 & 102 & -28 & $-27.45 \%$ \\
\hline II & Biotite gneiss with muscovite & 56 & 87 & -31 & $-35.63 \%$ \\
\hline 12 & Hornblende syenite & 34 & 47 & -13 & $-27.66 \%$ \\
\hline 13 & Hornblende syenite & 73 & 72 & I & $1.39 \%$ \\
\hline 14 & Monzogranite & 2,043 & 3,281 & -1238 & $-37.73 \%$ \\
\hline 16 & Biotite monzogranite & 127 & 132 & -5 & $-3.79 \%$ \\
\hline 17 & Biotite monzogranite & 1,800 & 2,394 & -594 & $-24.81 \%$ \\
\hline 18 & Biotite gneiss with muscovite & 9,611 & 10,300 & -689 & $-6.69 \%$ \\
\hline 20 & Biotite gneiss & 110 & 234 & -124 & $-52.99 \%$ \\
\hline 21 & Gneiss with muscovite & 241 & 844 & -603 & $-71.45 \%$ \\
\hline 22 & Biotite monzogranite & 353 & 408 & -55 & $-13.48 \%$ \\
\hline 25 & Biotite granodiorite & 42 & 139 & -97 & $-69.78 \%$ \\
\hline 26 & Calcarenite palesparite & 35 & 33 & 2 & $6.06 \%$ \\
\hline 29 & Monzogranite & 374 & 403 & -29 & $-7.20 \%$ \\
\hline 30 & Syenogranite & 117 & $|3|$ & -14 & $-10.69 \%$ \\
\hline 32 & Hornblende quartz mangerite & 34 & 85 & -51 & $-60.00 \%$ \\
\hline 33 & Quartz mangerite & 34 & 46 & -12 & $-26.09 \%$ \\
\hline 34 & Monzogranite & 701 & $|, 77|$ & -1070 & $-60.42 \%$ \\
\hline 35 & Monzogranite & 3,984 & 3,619 & 365 & $10.09 \%$ \\
\hline \multicolumn{2}{|l|}{ Average } & & & -222 & $-25.39 \%$ \\
\hline \multicolumn{2}{|c|}{ Standard deviation } & & & 382 & 0.25 \\
\hline
\end{tabular}

mineral body there is an intrinsic heterogeneity in the material that cannot be neglected. Homogeneity is an unachievable condition of zero heterogeneity (43). Therefore, each batch of marketed material must be evaluated by the proposed method. Batch sampling must be non-bias (accurate samples) and provide reproducible (precise) samples, thus making them representative of the batch (44).

Samples taken from a batch should be analyzed employing a portable contamination monitor. If the mean value of beta and gamma counts, discounted from the background, is higher than $10 \mathrm{cps}$ and/or the alpha count is different from zero, then the ${ }^{222} \mathrm{Rn}$ and ${ }^{220} \mathrm{Rn}$ exhalation rates and the Gamma Index should be assessed. If the ${ }^{222} \mathrm{Rn}$ exhalation rate is higher than the value considered acceptable for a specific room, the sample should be submitted for surface treatment before being released for indoor use. Batches approved according to the limit criteria could be used for indoors if they meet mass and location specifications. The use of such batches in the floor covering of a bedroom or institutional dormitory should be avoided, since a human being spends, on average, 33\% of their time sleeping, which results in a very high exposure time.

\section{Conclusions}

This research is based on case studies of radiometric analysis of building materials, notably dimension stone. The objective of this research was to provide concrete, practical, and economical quantification procedure that aims at the health protection of people who might be exposed to these materials.

In particular, the research highlighted the following points:

1. The primary natural alpha radiations from building materials are due to radon $\left({ }^{222} \mathrm{Rn}\right)$ and thoron $\left({ }^{220} \mathrm{Rn}\right)$. While the first one is the object of various national regulations and international recommendations from the WHO, the second one, although in no way less critical than the first one, is often disregarded, and, in our opinion, it does not receive enough coverage by policymakers. 


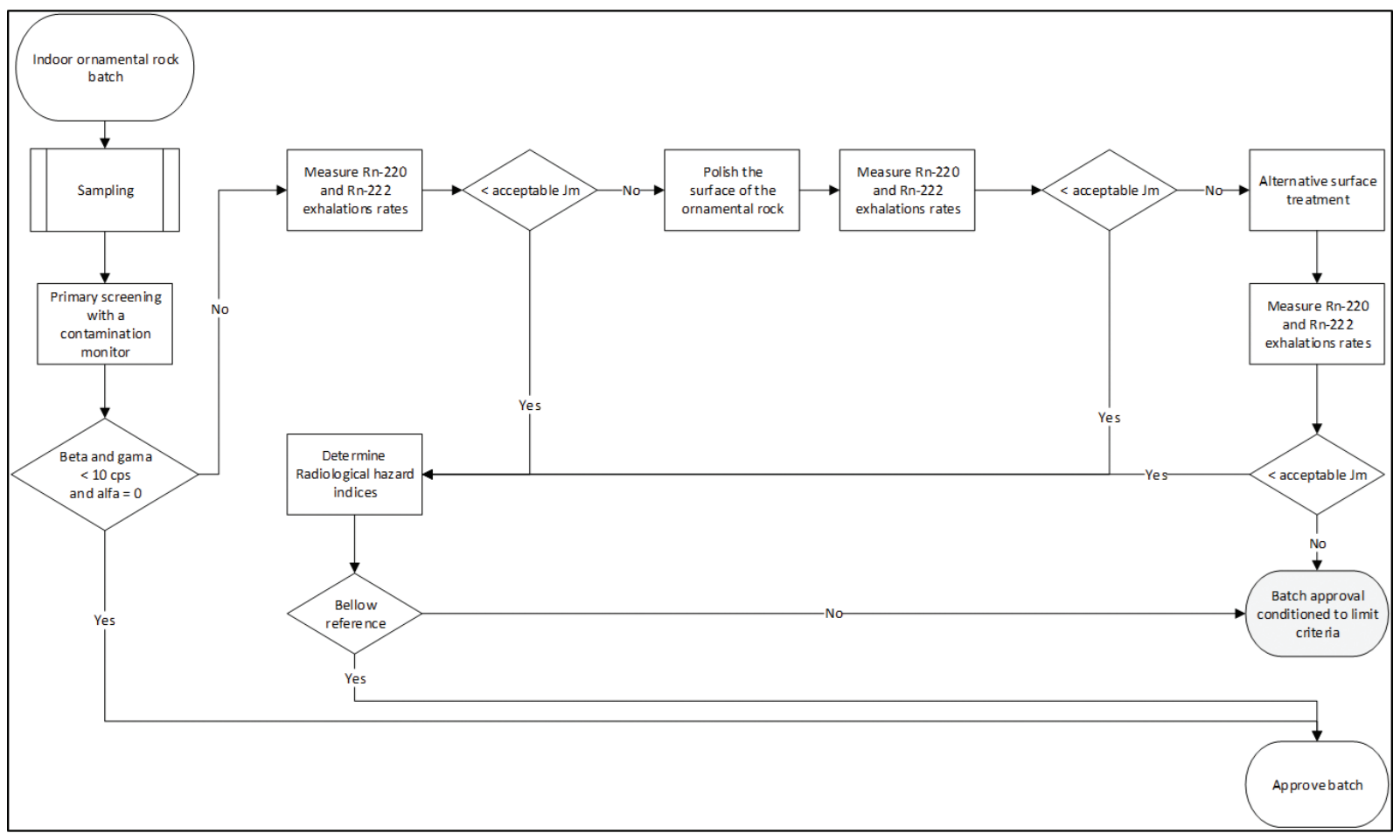

Fig. 9. A proposed method for radiologically evaluating indoor use of dimension stone.

2. Radon and thoron exhalations do not always correlate with the Gamma Index as the gas exhalation rate depends on physical parameters of the rock, such as humidity, permeability, density, and the roughness of the surface. This work demonstrated that radon and thoron exhalations could be significantly impacted when the surfaces of materials are polished.

3. The present research verified the feasibility of quantifying radon and thoron exhalations and proposed an analytical procedure that could define limits for the application of materials, particularly in the case of indoor applications of dimension stone.

Summing up, setting a new regulation for radon and thoron exhalations could be useful, thus complementing the one commonly defined as Gamma Index. This regulation could also be applied as a quality label for products in the case of import/export materials as well as for private sales.

\section{ACKNOWLEDGMENTS}

The authors would like to thank the following: CHUV's Institut de Radiophysique, Dr. Cristopher Murith (Swiss Federal Government) and Prof. Dr. Renato de Moraes (Universidade de São Paulo) for technical support, Dr. Nivaldo Silva (Comissão Nacional de Energia Nuclear CNEN) for the gamma spectrometry measurements, and
Prof. Dr. Sandra Soares (Universidade da Beira Interior) and Prof. Dr. Fabiano Cabañas Navarro (Universidade Federal de Alfenas) for their thorough review of the article.

\section{Conflict of interest and funding}

The authors declare no potential conflicts of interest.

The authors thank CAPES Foundation and Prof. Dr. Sérgio Médici (Universidade de São Paulo) for financial support.

\section{References}

1. Vives i Batlle J, Ulanovsky A, Copplestone D. A method for assessing exposure of terrestrial wildlife to environmental radon $\left({ }^{222} \mathrm{Rn}\right)$ and thoron $\left({ }^{220} \mathrm{Rn}\right)$. Sci Tot Environ. 2017; 605-606: 569-577. doi: 10.1016/j.scitotenv.2017.06.154

2. EC, FAO, ILO, OECD/NEA, PAHO, UNEP, et al. Radiation protection and safety of radiation sources: international basic safety standards. General Safety Requirements Part. 3. Vienna: IAEA; 2014.

3. Lantz PM, Mendez D, Philbert MA. Radon, smoking and lung cancer: the need to refocus control policy. Am J Public Health. 2013; 103(3): 443-447. doi: 10.2105/AJPH.2012.300926

4. Kreuzer M, Sogl M, Brüske I, Möhner M, Nowak D, Schnelzer $\mathrm{M}$, et al. Silica dust, radon and death from non-malignant respiratory diseases in German uranium miners. Occup Environ Med. 2013; 70: 869-875. doi: 10.1136/oemed-2013-101582

5. Vienneau D, de Hoogh K, Hauri D, Vicedo-Cabrera AM, Schindler C, Huss A, et al. Effects of radon and UV exposure on skin cancer mortality in Switzerland. Environ Health Perspect. 2017; 125(6): 67009-67007. doi: 10.1289/EHP825 
6. ICRP. Radiological Protection against Radon Exposure. ICRP Publication 126. Ann. ICRP 2014; 43(3): 77.

7. Ajrouche R, Ielsch G, Cléro E, Roudier C, Gay D, Guillevi J, et al. Quantitative health risk assessment of indoor radon: a systematic review. Radiat Protect Dosimetry. 2017; 177(1-2): 69-77. doi: 10.1093/rpd/ncx152

8. Nuccetelli C, Pontikes Y, Leonardi F, Trevisi R. New perspectives and issues arising from the introduction of (NORM) residues in building materials: a critical assessment on the radiological behavior. Constr Build Mater. 2015; 82: 323-331. doi: 10.1016/j.conbuildmat.2015.01.069

9. Darby S, Hill D, Auvinen A, Barros-Dios JM, Baysson H, Bochicchio F, et al. Radon in homes and risk of lung cancer: collaborative analysis of individual data from 13 European case-control studies. BMJ. 2004; 330(7485): 223-226. doi: 10.1136/ bmj.38308.477650.63

10. Lubin JH, Wang ZY, Boice JD, Yi Xu Z, Blot WJ, De Wang L, et al. Risk of lung cancer and residential radon in China: pooled results of two studies. Int J Cancer. 2004; 109(1): 132-137. doi: $10.1002 /$ ijc. 11683

11. Krewski D, Lubin J, Zielinski J, Alavanja M, Catalan V, Field R, et al. Residential radon and risk of lung cancer: a combined analysis of 7 North American case-control studies. Epidemiology. 2005; 16(2): 137-145. doi: 10.1097/01.ede.0000152522.80261.e3

12. Gray A, Read S, Mcgale P, Darby S. Lung cancer deaths from indoor radon and the cost effectiveness and potential of polices reduce them. BMJ. 2009; 338: 11. doi:10.1136/bmj.a3110

13. Field RW, Steck DJ, Smith BJ, Brus CP, Fisher EL, Neuberger JS, et al. Radiation protection - radon. Am J Epidemiol. 2000; 151(11): 1091-110. doi: 10.1093/oxfordjournals.aje.a010153

14. Sas Z, Somlai J, Jónas J, Szeiler G, Kóvacs T, Gyongyosi CS, et al. Radiological survey of Hungarian clays; radon emanation and exhalation influential effect of sample and internal structure conditions. Rom J Physics. 2013; 58: S243-S250.

15. Tsapalov A, Gulabyants L, Livshits MKK, Kovler K. New method and installation for rapid determination of radon diffusion coefficient in various materials. J Environ Radioact. 2014; 130: 7-14. doi: 10.1016/j.jenvrad.2013.12.010

16. Ayinmode BO, Famakinwa RO, Ajayi JO. Assessment of natural radioactivity in concrete block, extruded clay brick, and mud brick taken from Ogbomoso, Southwestern, Nigeria. Anadolu Univ J Sci Technol. 2012; 23-9. Available from: https://hdl. handle.net/11421/1561 [cited 10 November 2018].

17. Chao S, Lu X, Zhang M, Pang L. Natural radioactivity level and radiological hazard assessment of commonly used building material in Xining, China. J Radioanal Nucl Chem. 2014; 300(2): 879-885. doi: 10.1007/s10967-014-3065-6

18. El Hajj TM, Silva PSC, Gandolla MPA, Dantas GASA, Santos A, Delboni Jr, H. Radiological hazard indices and elemental composition of Brazilian and Swiss ornamental rocks. Braz $\mathrm{J}$ Radiat Sci. 2017; 5(2): 1-29. doi: 10.15392/bjrs.v5i2

19. Majid AA, Ismail AF, Yasir MS, Yahaya R, Bahari I. Radiological dose assessment of naturally occurring radioactive materials in concrete building materials. J Radioanal Nuclear Chem. 2013; 297(2): 277-284. doi: 10.1007/s10967-012-2387-5

20. Kovler K, Haquin G, Manasherov V, Ne'eman E, Lavi N. Natural radionuclides in building materials available in Israel. Build Environ. 2002; 37(5): 531-537. doi: 10.1016/ S0360-1323(01)00048-8

21. European Commission. Council directive 2013/59/Euratom of 5 Dec. 2013 laying down basic safety for protection against arising from exposure to ionizing radiation, and repealing directives 89/618/Euratom, 90/641/Euratom, 96/29/Euratom,
97/43/Euratom and 2003/122/Euratom. 2014; 13: 1-73. Available from: http://data.europa.eu/eli/dir/2013/59/oj, [cited 06 November 2016].

22. European Commission. Radiological protection principles concerning the natural radioactivity of building materials. Radiation protection no. 112. Luxemburg: Directorate-General, Environment, Nuclear Safety and Civil Protection; 1991.

23. Fojtíková I, Ženatá I, Timková J. Radon in workplaces - Czech approach to EU BSS implementation. Radiat Protect Dosimetry. 2017; 177(1-2): 104-111. doi: 10.1093/rpd/ncx180

24. Navratilova Rovenska K, Thinova L, Neznal M. Summary of the eighth conference on protection against radon at home and at work and the 13th workshop on the geological aspects of radon risk mapping. Radiati Protect Dosimetry. 2017; 177(1-2): 3-6. doi: 10.1093/rpd/ncx158

25. WHO. WHO handbook on indoor radon: a public health perspective. Geneva: WHO Press; 2009.

26. Bochicchio F, Venoso G, Antignani S, Carpentieri C. Radon reference levels and priority areas considering optimisation and avertable lung cancers. Radiat Protect Dosimetry. 2017; 177(1-2): 87-90. doi: 10.1093/rpd/ncx130

27. Steger F, Grün K. Radioactivity in building materials ÖNORM S 5200: a standard in Austria to limit natural radioactivity in building materials (revised and definite version). Radon in the Living Environment. 1999; 219-224.

28. International Atomic Energy Agency (IAEA). Radiation protection and safety of radiation sources: international basic safety standards. IAEA safety standards series GSR Part 3. Vienna: International Atomic Energy Agency; 2014. Report No: 978-92-0-135310-8.

29. Kropat G, Bochud F, Jaboyedoff M, Laedermann JP, Murith C, Palacios M, et al. Major influencing factors of indoor radon concentrations in Switzerland. J Environ Radioact. 2014; 129: 7-22. doi: 10.1016/j.jenvrad.2013.11.010

30. Nuccetelli C, Bochicchio F. The thoron issue: monitoring activities, measuring techniques and dose conversion factors. Radiat Protect Dosimetry. 1998; 78(1): 59-64. doi: 10.1093/oxfordjournals.rpd.a032334

31. Ishikawa T, Tokonami S, Nemeth C. Calculation of dose conversion factors for thoron decay products. J Radiol Protect. 2007; 27(4): 447-456. doi: 10.1088/0952-4746/27/4/005

32. Lane-Smith D, Wong FK. Inadequacy of thoron dose calculations from thoron progeny measurement alone. Radiat Protect Dosimetry. 2016; 171(2): 179-180. doi: 10.1093/rpd/ ncw054

33. Keller G, Folkerts KH, Muth H. Discussing possible standards of natural radioactivity in building materials. Radiat Environ Biophys. 1987; 26(2): 143-150. doi: 10.1007/ BF01211408

34. Bonczyk M, Samolej K. Testing of the radon tightness of beakers and different types of sealing used in gamma-ray spectrometry for 226Ra concentration determination in NORM. J Environ Radioact. 2019; 205-206: 55-60. doi:10.1016/j. jenvrad.2019.05.007

35. Keller G, Hoffmann B, Feigenspan T. Radon permeability and radon exhalation of building materials. Sci Tot Environ. 2001; 272(1): 85-89. doi: 10.1016/S0048-9697(01)00669-6

36. Ishimori Y, Lange K, Martin P, Mayya YS. Measurement and calculation of radon releases from NORM residues. IAEA; 2013. Technical Reports Series no. 474.

37. GRAETZ. Products: CoMo 170 [Online]. Available from: http://www.graetz.com/como-170+M52087573ab0.html [cited 06 November 2016]. 
38. Myatt TA, Allen JG, Minegishi T, Mccarthy WB, Stewart JH, Macintosh DL, et al. Assessing exposure to granite countertops - part 1: radiation. J Expo Sci Environ Epidemiol. 2010; 20(3): 273-280. doi: 10.1038/jes. 2009.44

39. Allen JG, Minegishi T, Myatt TA, Stewart JH, Mccarthy JF, Macintosh DL. Assessing exposure to granite countertops part 2: radon. J Expo Sci Environ Epidemiol. 2010; 20(3): 263-272. doi: 10.1038/jes.2009.43

40. Bem H, Gasiorowski A, Szajerski P. A fast method for the simultaneous determination of soil radon $\left({ }^{222} \mathrm{Rn}\right)$ and thoron $\left({ }^{220} \mathrm{Rn}\right)$ concentrations by liquid scintillation counting. Sci Tot Environ. 2020; 709, 136127: 1-11. doi: 10.1016/j. scitotenv.2019.136127

41. Al-Hubail J, Al-Azmi D. Radiological assessment of indoor radon concentrations and gamma dose rates in secondary school buildings in Kuwait. Constr Build Mater. 2018; 183: 1-6. doi: 10.1016/j.conbuildmat.2018.06.152
42. Gao GWW, Tang YH, Tam CM, Gao XF. Anti-radon coating for mitigating indoor radon concentration. Atmos Environ. 2008; 42(37): 8634-8639. doi: 10.1016/j.atmosenv. 2008.08.009

43. Gy P. Sampling of heterogeneous and dynamic material systems: theories of heterogeneity, sampling and homogenizing. Data Handl Sci Technol. 1992; 10(1): 654.

44. Pitard FF. Pierre Gy's sampling theory and sampling practice: heterogeneity, sampling correctness, and statistical process control. Bacon Raton, FL: CRC Press; 1993.

\section{*Thammiris Mohamad El Hajj}

Rodovia José Aurélilio Vilela, I 1999

377I 5-400, Poços de Caldas-MG

Brazil

Email: thammiris.hajj@unifal-mg.edu.br 